\title{
Character strengths in the Brazilian northeast region: Contributions of personality beyond age and sex
}

\author{
Forças de caráter no nordeste brasileiro: contribuições \\ da personalidade para além de idade e sexo
}

Ricardo Neves COUTO ${ }^{1}$ iD 0000-0001-9989-4857
Patrícia Nunes da FONSÊCA ${ }^{1}$ iD) 0000-0002-6322-6336

\begin{abstract}
The objective was to verify to what extent the personality traits explain character strengths, controlling the effect of age and sex. A total of 251 individuals living in the Northeast region of Brazil $\left(M_{\text {age }}=18.51, S D=9.03\right), 66.9 \%$ of which were women, answered a booklet containing the Character Strengths Scale, Five Major Factors Inventory (Big Five) and demographic issues. From the correlations, followed by multiple hierarchical regressions, it was found that age and sex were important to explain some strengths. Controlling the effect of these demographic variables, it was observed that the kindness, conscientiousness, extroversion and openness to experience personality traits directly explained these strengths, unlike the neuroticism trait, which did it inversely. Backed by the empirical evidence, it can be concluded that character strengths can be explained by personality traits and demographic variables (sex and age), collaborating with the expansion of knowledge in the area and understanding the positive aspects of the human being.
\end{abstract}

Keywords: Character strengths; Northeast; Personality; Social Psychology.

\section{Resumo}

Objetivou-se verificar em que medida os traços de personalidade explicam as forças de caráter, controlando o efeito da idade e do sexo. Participaram 251 pessoas residentes no nordeste brasileiro $\left(M_{\text {idded }}=18,51, D P=9,03\right), 66,9 \%$ mulheres,

\footnotetext{
$\checkmark v \nabla$

1 Universidade Federal da Paraíba, Centro de Ciências Humanas Letras e Artes, Departamento de Psicologia Social. Via Expressa Padre Zé, s/n., Conjunto Presidente Castelo Branco III, 58033-455, João Pessoa, PB, Brasil. Correspondência para/Correspondence to: R.N. COUTO. E-mail: <r.nevescouto@gmail.com>

Support: Conselho Nacional de Desenvolvimento Científico e Tecnológico (National Council for Scientific and Technological Development) (Process \# 30778/2018-5) and the Coordenação de Aperfeiçoamento de Pessoal de Nivel Superior (Coordination for Higher Education Staff Development).

Article elaborated on the thesis of R.N. COUTO, entitled "Forças de caráter no nordeste brasileiro: contribuições da personalidade para além de idade e sexo" Universidade Federal da Paraíba, 2019.

Como citar este artigo/How to cite this article

Couto R. N., \&. Fonsêca P. N. (2019). Character strengths in the Brazilian northeast region: contributions of personality beyond age and sex. Estudos de Psicologia (Campinas), 36, el8137. http://dx.doi.org/10.1590/1982-0275201936e180137
} 
respondendo um livreto contendo a Escala de Forças de Caráter, Inventário dos Cinco Grandes Fatores e questões demográficas. A partir de correlações, seguidas de regressões múltiplas hierárquicas, verificou-se que idade e sexo foram importantes para explicar algumas forças. Controlando o efeito dessas variáveis demográficas, observou-se que os traços de personalidade amabilidade, conscienciosidade, extroversão e abertura à experiencia explicaram diretamente as forças, ao contrário do traço neuroticismo, que o fez de maneira inversa. Respaldados pelas evidências empíricas, conclui-se que as forças de caráter podem ser explicadas pelos traços de personalidade e variáveis demográficas (sexo e idade), colaborando com a expansão do conhecimento na área e no entendimento dos aspectos positivos do ser humano.

Palavras-chave: Forças de caráter; Nordeste; Personalidade; Psicologia Social.

Literature in the field of psychology, up until the 1990s, converged into studies on subjects that cause suffering (e.g., depression, disasters). However, since 1998, with the Positive Psychology movement, there has been an increasing interest in human potentialities (Seligman \& Csikszentmihalyi, 2000). In an attempt to balance the focus, the movement seeks investigations that provide positive experiences, communities and institutions (e.g. schools, companies), as well as highlighting the strengths of the individual's character, which has advanced internationally from a theoretical model based on the virtues of the human being (McGrath, 2015).

Each person has a character, represented as a central set of characteristics that must be developed individually through personal effort and learning (Peterson \& Seligman, 2004). In order to be constructed, it is necessary for the individual to absorb the contents in a plural way, which are expressed in the different situations of the daily life, that is, a person cannot be considered only honest, modest, or creative because character is formed by psychological mechanisms, called character strengths, which bring together all the strengths of the individual as a profile (Niemiec, 2013).

In this way, strengths are basic building elements of character and essential for people to become better individuals in different situations. Therefore, the use of strengths, the authentic capacity of the individual, provides an ideal functioning with more quality and less pathologies, consequently maximizing the stability and generality of a satisfying life (Noronha \& Barbosa, 2016).

In addition, these strengths can be trained and, consequently, becoming desired by being morally valued and by bringing benefits to the individual and to others, taking into account that productive and pleasurable experiences come from a good character (Noronha \& Barbosa, 2018). Given this importance in people's lives, Peterson and Seligman (2004) propose a model, described further on, that brings together 24 strengths, theoretically distributed in six virtues that represent what is valued most in the daily lives of people from the judgment of philosophers, religious practitioners and researchers.

It should be noted that character strengths are influenced by environmental factors (Steger, Hicks, Kashdan, Krueger, \& Bouchard, 2007) and personal characteristics, especially age and sex. In addition, character strengths are influenced by heredity (Steger et al., 2007) and are stable over time, but not unchanging. Thus, they approach the concept of personality traits (Park \& Peterson, 2009), variables regarded as descriptions of people in terms of relatively stable patterns of behavior, thoughts and emotions (Parks-Leduc, Feldman, \& Bardi, 2015), with which there is empirical evidence of relationships (Depaula, Azzollini, Cosentino, \& Castillo, 2016; J. Neto, Neto, \& Furnham, 2014).

Specifically in Brazil, Noronha and Campos (2018) demonstrate that personality traits contribute to the explanation of strengths, however, they assert that there is still no consensus about the relationship and suggest new studies, since they restricted the sample in two states of the Southeast region, and only used university students. From this and all the above, the following question has been asked: How do personality traits explain character strengths, controlling the effect of age and sex?

In order to answer this question and to proceed with the identification of elements that contribute 2 to the use of strengths by the human being on a daily basis, the present study aims at verifying the extent 
to which personality traits explain character strengths, controlling the effect of age and sex, specifically seeking to verify the pattern of relationship between traits and age with the individual's strengths, as well as to ascertain the difference between the sexes. Next, before demonstrating the empirical results, concepts of the discussed constructs will be presented.

\section{- Character Strengths}

The interest in the study of character strengths, dating from the beginning of the 21st century, starts from the idea that Positive Psychology turns to experiences that maximize happiness (Romero, Guajardo, \& Sanchez, 2016). Especially, Peterson and Seligman (2004) proposed a universal classification, Values in Action (VIA), bringing together the 24 strengths as psychological means that serve as a way to the six virtues in order to highlight the healthy strengths of the individual.

The VIA is considered to be a shocking criticism of the prevalence of traditional studies about human pathologies and abilities to do something negative, so Peterson and Seligman (2004) proposed the classification that can be viewed as "a manual of sanity" (Noronha \& Barbosa, 2016). It should be borne in mind that this proposed classification should not be seen as prescriptive, but only as descriptive (Niemiec, 2013).

In cross-cultural studies, with different nations, including Brazil, Park, Peterson, and Seligman (2006) and McGrath (2015) corroborate the universality of the proposed model, group nations by cultural similarities, but emphasize that there should not be generalizations, since the ranking of strengths is individual and influenced by the particularities of each region. In addition, it is emphasized that the measurement of strengths is performed independently, with the evaluation being done in a global way, since they are interrelated and mutually influenced (Seibel, DeSousa, \& Koller, 2015).

For this task of measurement and evaluation, the 240 item-VIA Inventory of Strengths (VIA-IS), which is used internationally and evaluates each strength through 10 items, has been elaborated. As for the structure factor, it should be noted that originally Peterson and Seligman (2004) found a solution of five factors, but chose to describe the model of six virtues. Noronha, Dellazzana-Zanon and Zanon (2015), based on the VIA and the proposed model, constructed a more parsimonious Brazilian scale, composed of 71 items, which are distributed, in three items for each of the strengths, except for the appreciation of beauty, which was composed of only two.

These instruments aid in the measurement and advancement of the studies with character strengths, and it is possible to observe that these strengths present a positive relation with age, specifically, those that seem to require more maturity (e.g., self-regulation, forgiveness, critical thinking (Linley et al., 2007; Noronha \& Barbosa, 2016).

However, researchers suggest that the absence of statistically significant differences between age groups (Neto et al., 2014; Park, Peterson, \& Seligman, 2004). In addition, studies indicate significant differences regarding sex, pointing to women with a higher prevalence in love, kindness, spirituality and gratitude, and men in bravery and creativity (Azañedo, Fernández-Abascal, \& Barraca, 2014; Peterson \& Park, 2006; Romero et al., 2016).

In addition, relationships with resilience (Haridas, Bhullar, \& Dunstan, 2017), parental styles (Noronha \& Batista, 2017), cultural intelligence (Depaula et al., 2016), life satisfaction (Noronha \& Martins, 2016), subjective well-being (Oliveira, Nunes, Legal, \& Noronha, 2016), among others. In this paper, we present the results of the present study (Neto et al., 2014; Noronha \& Campos, 2018), which is also the focus of the present research.

Among them, the studies that theoretically and empirically approach strengths as personality traits (Neto et al., 2014; Noronha \& Campos, 2018) are highlighted, a construct that, being the focus of the present investigation, will be introduced next. 
In psychology, personality is remarkably one of the most important topics for predicting several aspects of human life (behaviors, feelings, emotions), a fact that has been demonstrated in different investigations (Azucar, Marengo, \& Settanni, 2018; L. Li, Li, Hao, Guan, \& Zhu, 2014). In the task of describing the construct, it is found in the literature different theoretical frameworks, a scenario that requires the researcher to define the framework that will be used (Hall, Lindzey, \& Campbell, 2000).

The present investigation uses the Big Five model (the five main personality factors) for it is well accepted internationally, being one of the most considered in studies (McCrae \& Costa, 1987; McCrae \& John, 1992). In addition, its structure is universal and represents a modern version of the factorial and trait theories, receiving the nomenclature of "the Big Five" because it is able to integrate different definitions of personality in a parsimonious way (Nunes, Hutz, \& Nunes, 2010).

In this model, the five personality factors bring together the way people think, feel and act on a dayto-day basis. In this sense, they are organized into measurable traits that independently evaluate the individual attributes, which, genetically influenced, are stable over time and in different circumstances. However, they can be altered by social interactions and motivational or affective influences (McCrae \& Costa, 1997; McCrae \& John, 1992).

The Big Five often receive different denominations in different cultures. However, it is emphasized that the definitions and characteristics of each trait are consensual. In this direction, in Brazil, they are regularly identified as: (1) Openness to experience (or change); (2) Conscientiousness; (3) Extroversion; (4) Kindness (sociability); and (5) Neuroticism (emotional instability) (Silva \& Nakano, 2011).

Taking into account the taxonomy reviewed by John, Naumann, and Soto (2008) and the definitions presented by Liu and Campbell (2017) and Monteiro et al. (2015), the openness to experience factor includes the tendency and ability to seek, detect and understand information, which is expressed in curiosity, boldness, creativity and search for novelties, and emphasize new experiences. Conscientiousness is defined as the inclination to follow rules, to be obedient, organized and precise, besides preferring not to receive immediate gratifications, for prioritizing long-term goals.

In addition, extroversion refers to the motivations directed towards socialization, positive emotions, optimism and joy, besides being linked to the search for excitement, sensations and social attention. The kindness trait portrays the person's interpersonal orientation towards others, involving friendliness, solidarity, kindness, trust, and harmonious behavior. On the other hand, the neuroticism trait reflects an individual's emotional instability and is associated with anxiety, depressive affections and negative emotionality (John et al., 2008; Liu \& Campbell, 2017; Monteiro et al., 2015).

In research, these five personality factors are taken as explanatory variables of different psychological phenomena. It is worth noting the significant relationship between happiness (Goldsmith, 2017), selfesteem (Pilarska, 2018), resilience (Oshio, Taku, Hirano, \& Saeed, 2018) and, as previously mentioned, with character strengths (Neto et al., 2014, Noronha \& Campos, 2018). In this way, in order to achieve the proposed objectives, it is presented evidence of the relationship and the prediction of personality traits with the character strengths, controlling the effect of demographic variables (age and sex).

\section{Method}

\section{Participants}

A convenience sample (non-probabilistic) was used with 251 people, with the inclusion criterion being: individuals, aged 18 years or older and living in the northeast region. Participants came from all nine 
states in the Northeast, mostly from Paraiba (40.5\%) and Piaui (18.3\%). Their age ranged from 18 to 72 years $(M=26.51, S D=9.03), 66.9 \%$ were female and $74.5 \%$ were single, the majority $(33.5 \%)$ of which reported having an average family income between BRL 2862.00 and BRL 5724.00; as for education, 51.4\% of these individuals did not finish college.

\section{Instruments}

Character Strengths Scale (CSS). Elaborated in Brazil (Noronha et al., 2015), it measures the 24 character strengths, with three questions to evaluate them, except for the appreciation of beauty, which is composed of two questions, in a total of 71 items (e.g., item 14 "I live my life in a good mood" and item 12. "I am patient"), answered on a Likert scale ranging from "nothing to do with me" $(0)$ to "everything to do with me"(4). The greater the result of the sum of the items of each strength, the more evident will be their presence in the life of the individual. In the construction and validation research, it presented a unifactory structure with Cronbach's alpha: general $=0.93$; in this study the alpha was: 0.95 .

The Big Five Inventory (BFI) is a measure elaborated by John, Donahue, and Kentle (1991) composed by 44 items. Adapted for Brazil (Andrade, 2008), its factors present alphas varying from 0.68 (Openness and Conscientiousness) to 0.76 (Extroversion). It will use a reduced version, composed of 20 items, choosing the four with the highest factor loads in the study of Schmitt et al. (2007). The items are structured in sentences (e.g., item 4. Likes to cooperate with others; item 9. Is a kind person, has consideration for others), and the individual should indicate how one sees oneself (I see myself as someone who ...), using a five-point Likert Scale, ranging from (1) "strongly disagree" to (5) "strongly agree".

Sociodemographic questionnaire. It is a set of questions (e.g., age, sex, income) that aims to characterize the participants, as well as being considered predictors of character strengths.

\section{Procedures}

The implementation of the project was approved by the Research Ethics Committee of the Universidade Federal da Paraíba (UFPB, Federal University of Paraíba) (CAA: 77974517.8.0000.5188; protocol number: 2.350.522), following the norms of resolutions 466/12 and 510/16 of the National Health Council. After their approval, the instruments were applied in two ways, both face-to-face and online. In the former, three properly trained collaborators visited the individuals' homes, randomly chosen in some Northeastern region cities, in addition to large circulation spaces (e.g., city squares, shopping malls). In the latter, through the platform Google Docs, the instruments were available in social networks and sent to the emails of the participants.

At the time, the people who were invited to participate were also informed of the general objective of the study, the voluntary nature of it, the anonymity of the answers and the possibility of giving up at any time, without any burden to the volunteer. The only risk a volunteer would have would be a possible embarrassment when reading the items. In order to admit the participants' consent, they were asked to sign an Informed Consent Term before responding to the instruments, which was carried out in an average of 15 minutes from start to completion.

\section{Data analysis}

Descriptive statistics (mean, standard deviation, and frequency estimates) were performed through the SPSS software (version 23) to characterize the participants, in addition to Pearson's r correlation coefficient 
to verify the relationship between personality traits and character strengths. Then, multiple hierarchical regressions were calculated to identify the predictive power of demographic variables and personality traits in the explanation of character strengths.

\section{Results}

Initially, Pearson correlations were made with the five personality traits (Big Five) and the 24 character strengths. The results, in Table 1, indicated that the Openness to Experience trait, except for impartiality, showed a positive and statistically significant correlation $(p<0.05)$ with all strengths, varying the magnitude of Pearson's r of 0.14 (modesty) up to 0.55 (creativity). This pattern was also found in conscientiousness, with magnitudes ranging from 0.16 (appreciation of beauty) to 0.52 (leadership). Extroversion did not present a statistically significant correlation with prudence and self-regulation; however, with the other 22 strengths, positive correlations were observed, with the $r$ coefficient varying from 0.17 (critical thinking) to 0.67 (social intelligence).

Table 1

Descriptive statistics and correlation between character strengths and personality traits

\begin{tabular}{|c|c|c|c|c|c|c|c|}
\hline \multirow{2}{*}{ Strengths } & \multicolumn{2}{|c|}{ Descriptive: Strengths } & \multicolumn{5}{|c|}{ Big Five } \\
\hline & $M$ & $S D$ & $\mathrm{O}$ & C & $E$ & K & $\mathrm{N}$ \\
\hline Creativity & 7.40 & 2.19 & $0.55^{* *}$ & $0.42^{* *}$ & $0.36^{* *}$ & $0.21^{* *}$ & -0.09 \\
\hline Curiosity & 9.57 & 2.12 & $0.41^{* *}$ & $0.29^{* *}$ & $0.33^{* *}$ & $0.30^{* *}$ & 0.02 \\
\hline Critical thinking & 9.01 & 1.97 & $0.27^{* *}$ & $0.33^{* *}$ & $0.17^{\star *}$ & $0.24^{* *}$ & $-0.17^{* *}$ \\
\hline Love for learning & 9.06 & 2.37 & $0.38^{* *}$ & $0.32^{* *}$ & $0.36^{* *}$ & $0.27^{* *}$ & -0.03 \\
\hline Wisdom & 7.34 & 2.27 & $0.26^{* *}$ & $0.34^{* *}$ & $0.33^{* *}$ & $0.32^{* *}$ & $-0.17^{* *}$ \\
\hline Bravery & 7.69 & 2.62 & $0.30^{* *}$ & $0.29^{* *}$ & $0.43^{* *}$ & $0.45^{* *}$ & -0.09 \\
\hline Perseverance & 9.03 & 2.42 & $0.21^{* *}$ & $0.50^{* *}$ & $0.28^{* *}$ & $0.22^{* *}$ & -0.10 \\
\hline Authenticity & 8.53 & 2.17 & $0.28^{* *}$ & $0.28^{* *}$ & $0.26^{* *}$ & $0.30^{* *}$ & 0.05 \\
\hline Vitality & 7.82 & 2.92 & $0.36^{* *}$ & $0.40^{* *}$ & $0.64^{* *}$ & $0.46^{* *}$ & $-0.16^{*}$ \\
\hline Love & 8.08 & 2.55 & $0.22^{* *}$ & $0.26^{* *}$ & $0.50^{* *}$ & $0.48^{* *}$ & -0.11 \\
\hline Goodness & 9.79 & 1.92 & $0.20^{* *}$ & $0.28^{* *}$ & $0.40^{* *}$ & $0.62^{* *}$ & -0.02 \\
\hline Social intelligence & 7.98 & 2.29 & $0.29^{* *}$ & $0.39^{* *}$ & $0.67^{* *}$ & $0.37^{* *}$ & -0.04 \\
\hline Citizenship principles & 8.53 & 2.26 & $0.36^{* *}$ & $0.40^{* *}$ & $0.49^{* *}$ & $0.47^{* *}$ & $-0.13^{*}$ \\
\hline Impartiality & 9.25 & 1.88 & 0.12 & $0.32^{* *}$ & $0.22^{* *}$ & $0.40^{* *}$ & 0.01 \\
\hline Leadership & 7.61 & 2.57 & $0.25^{* *}$ & $0.52^{* *}$ & $0.44^{* *}$ & $0.31^{* *}$ & -0.09 \\
\hline Forgiveness & 7.19 & 2.83 & $0.18^{* *}$ & $0.18^{* *}$ & $0.19^{* *}$ & $0.66^{* *}$ & $-0.18^{* *}$ \\
\hline Modesty & 9.20 & 2.10 & $0.14^{*}$ & $0.27^{* *}$ & $0.16^{*}$ & $0.45^{* *}$ & -0.06 \\
\hline Prudence & 8.67 & 2.33 & $0.20^{* *}$ & $0.26^{* *}$ & 0.06 & $0.27^{* *}$ & $-0.25^{* *}$ \\
\hline Self-regulation & 7.26 & 2.61 & $0.15^{*}$ & $0.29^{* *}$ & 0.09 & $0.25^{* *}$ & $-0.36^{* *}$ \\
\hline Appreciation of beauty & 6.28 & 1.52 & $0.31^{*}$ & $0.16^{*}$ & $0.42^{* *}$ & $0.30^{* *}$ & -0.04 \\
\hline Gratitude & 9.69 & 2.40 & $0.24^{* *}$ & $0.25^{* *}$ & $0.38^{* *}$ & $0.51^{* *}$ & -0.04 \\
\hline Mood & 7.69 & 2.86 & $0.40^{* *}$ & $0.20^{* *}$ & $0.62^{* *}$ & $0.44^{* *}$ & $-0.23^{* *}$ \\
\hline Hope & 9.04 & 2.63 & $0.21^{* *}$ & $0.24^{* *}$ & $0.41^{* *}$ & $0.42^{* *}$ & $-0.21^{* *}$ \\
\hline Spirituality & 8.82 & 3.17 & $0.24^{* *}$ & $0.25^{* *}$ & $0.40^{* *}$ & $0.43^{* *}$ & 0.01 \\
\hline
\end{tabular}

Note: ${ }^{*} p<0.05 ;{ }^{* *} p<0.001$. M: Mean; SD: Standard Deviation; C: Conscientiousness; E: Extroversion; K: Kindness; N: Neuroticism; O: 
Moreover, the kindness trait has positively correlated with all character strengths, showing magnitudes ranging from 0.21 (creativity) to 0.66 (forgiveness). Finally, the neuroticism trait was correlated only with nine strengths (critical thinking, sensibility, vitality, citizenship principles, forgiveness, prudence, self-regulation, mood and hope), but, unlike the other traits, it had negative correlations, with the r coefficient ranging from -0.16 (vitality) to -0.36 (self-regulation).

Finally, it was decided to evaluate the predictive power of the personality traits, controlling the effect of sex and age, in the character strengths performing hierarchical regression analyzes. In this way, the demographic variables (age and sex) were first inserted in the model, adding the traits that presented statistically significant correlations with each specific strength in the second step. Table 2 presents the results of the second step of this analysis.

It should be noted that when the demographic variables (age, sex) were introduced in the model, the results were significant $(p<0.05)$ in 13 strengths. However, with the insertion of personality traits in the second step, that is, after controlling for the effect of demographic variables, it was found that all strengths

Table 2

Second step of the hierarchical regressions between character strengths and personality traits

\begin{tabular}{|c|c|c|c|c|c|c|c|c|c|}
\hline \multirow{2}{*}{ Strengths } & \multicolumn{2}{|c|}{ Demographics } & \multicolumn{5}{|c|}{ Big Five } & \multicolumn{2}{|c|}{ Models } \\
\hline & Age & $\operatorname{Sex}^{\mathrm{a}}$ & O & C & $\mathrm{E}$ & K & $\mathrm{N}$ & $1^{\circ} R^{2}$ & $2^{\circ} R^{2}$ \\
\hline Creativity & 0.07 & $-0.12^{*}$ & $0.44^{* *}$ & $0.29^{* *}$ & 0.08 & -0.03 & & $0.05^{* *}$ & $0.40^{* *}$ \\
\hline Curiosity & -0.07 & -0.03 & $0.30^{* *}$ & $0.16^{*}$ & 0.11 & $0.14^{*}$ & & 0.03 & $0.25^{* *}$ \\
\hline Critical thinking & -0.07 & $0.12^{*}$ & $0.20^{* *}$ & $0.29^{* *}$ & -0.07 & $0.15^{*}$ & $-0.17^{*}$ & $0.02^{*}$ & $0.22^{* *}$ \\
\hline Love for learning & 0.10 & -0.02 & $0.24^{* *}$ & $0.19^{* *}$ & $0.14^{*}$ & $0.09^{*}$ & & 0.04 & $0.25^{* *}$ \\
\hline Wisdom & -0.03 & -0.07 & $0.12^{*}$ & $0.22^{* *}$ & $0.13^{*}$ & $0.17^{*}$ & $-0.17^{*}$ & 0.02 & $0.24^{* *}$ \\
\hline Bravery & 0.05 & $-0.10^{*}$ & 0.09 & $0.11^{*}$ & $0.22^{* *}$ & $0.30^{* *}$ & & $0.04^{*}$ & $0.31^{* *}$ \\
\hline Perseverance & 0.01 & -0.05 & 0.07 & $0.43^{* *}$ & 0.09 & 0.05 & & 0.02 & $0.26^{* *}$ \\
\hline Authenticity & $0.15^{*}$ & $0.14^{*}$ & $0.17^{*}$ & $0.16^{*}$ & 0.04 & $0.17^{*}$ & & $0.07^{* *}$ & $0.20^{* *}$ \\
\hline Vitality & $0.11^{*}$ & -0.07 & 0.08 & $0.17^{* *}$ & $0.44^{* *}$ & $0.18^{* *}$ & $-0.13^{*}$ & $0.08^{* *}$ & $0.52^{* *}$ \\
\hline Love & -0.09 & 0.06 & -0.02 & 0.09 & $0.37^{* *}$ & $0.31^{* *}$ & & 0.01 & $0.35^{* *}$ \\
\hline Goodness & 0.03 & 0.01 & -0.03 & 0.09 & $0.15^{*}$ & $0.54^{* *}$ & & $0.02^{*}$ & $0.42^{* *}$ \\
\hline Social intelligence & 0.01 & 0.04 & 0.07 & $0.24^{* *}$ & $0.29^{* *}$ & $0.16^{*}$ & & $0.02^{*}$ & $0.31^{* *}$ \\
\hline Citizenship principles & 0.08 & -0.03 & $0.14^{*}$ & $0.21^{* *}$ & $0.23^{* *}$ & $0.26^{* *}$ & $-0.13^{*}$ & $0.04^{*}$ & $0.41^{* *}$ \\
\hline Impartiality & $0.14^{*}$ & -0.01 & & $0.21^{* *}$ & -0.02 & $0.33^{* *}$ & & $0.05^{*}$ & $0.22^{* *}$ \\
\hline Leadership & -0.04 & -0.01 & 0.03 & $0.41^{* *}$ & $0.26^{* *}$ & 0.08 & & 0.01 & $0.36^{* *}$ \\
\hline Forgiveness & -0.08 & -0.07 & 0.04 & 0.05 & $-0.14^{*}$ & $0.70^{* *}$ & $-0.15^{*}$ & 0.01 & $0.49^{* *}$ \\
\hline Modesty & 0.06 & 0.07 & 0.03 & $0.17^{*}$ & $-0.11^{*}$ & $0.43^{* *}$ & & $0.02^{*}$ & $0.24^{* *}$ \\
\hline Prudence & -0.09 & -0.05 & $0.13^{*}$ & $0.19^{*}$ & & $0.19^{*}$ & $-0.26^{* *}$ & 0.01 & $0.20^{* *}$ \\
\hline Self-regulation & -0.06 & -0.08 & 0.07 & $0.26^{* *}$ & & $0.16^{*}$ & $-0.35^{* *}$ & 0.02 & $0.26^{* *}$ \\
\hline Appreciation of beauty & -0.01 & -0.02 & $0.14^{*}$ & 0.01 & $0.31^{* *}$ & $0.13^{*}$ & & 0.01 & $0.21^{* *}$ \\
\hline Gratitude & 0.06 & $0.14^{*}$ & 0.05 & 0.07 & $0.16^{*}$ & $0.40^{* *}$ & & $0.05^{*}$ & $0.32^{* *}$ \\
\hline Mood & $-0.10^{*}$ & -0.05 & $0.18^{*}$ & -0.03 & $0.48^{* *}$ & $0.19^{* *}$ & $-0.21^{* *}$ & 0.01 & $0.50^{* *}$ \\
\hline Hope & 0.05 & 0.05 & 0.03 & 0.08 & $0.24^{* *}$ & $0.27^{\star *}$ & $-0.20^{* *}$ & $0.02^{*}$ & $0.29^{* *}$ \\
\hline Spirituality & 0.04 & $0.21^{* *}$ & 0.06 & 0.08 & $0.22^{*}$ & $0.28^{* *}$ & & $0.07^{* *}$ & $0.29^{* *}$ \\
\hline
\end{tabular}

Note: ${ }^{*} p<0.05 ;{ }^{* *} p<0.001$; asex: 1 = Male and 2 = Female; R2: variance explained by the model; C: Conscientiousness; E: Extroversion; K: Kindness; $\mathrm{N}$ Neuroticism; O: Openness to experiences. 
were adequately explained. It is worth mentioning the increment that occurred in the explanation of the character strengths, with a variance explained ranging from 20\% (Authenticity) to 52\% (Vitality).

In Table 3, a summary of the relationships is made to facilitate the identification of the contribution of each personality trait. As for the variables taken as predictors, it is observed that the age variable explains directly the following strengths: authenticity, vitality, impartiality, and, indirectly, mood. As for sex, it has been shown that men score better in creativity and bravery, while in critical thinking, authenticity, gratitude and spirituality, women show a higher prevalence. Regarding the traits, it is verified that the openness to experience trait positively predicts the creativity, curiosity, critical thinking, love for learning, wisdom, authenticity, citizenship principles, prudence, appreciation of beauty and mood strengths.

Table 3

Summary of the relationships between character strengths and personality traits

\begin{tabular}{|c|c|c|c|c|c|}
\hline Strengths & $\mathrm{O}$ & C & $\mathrm{E}$ & K & $\mathrm{N}$ \\
\hline Creativity & $(+)$ & $(+)$ & & & \\
\hline Curiosity & $(+)$ & $(+)$ & & $(+)$ & \\
\hline Critical thinking & $(+)$ & $(+)$ & & $(+)$ & $(-)$ \\
\hline Love for learning & $(+)$ & $(+)$ & $(+)$ & $(+)$ & \\
\hline Wisdom & $(+)$ & $(+)$ & $(+)$ & $(+)$ & $(-)$ \\
\hline Bravery & & $(+)$ & $(+)$ & $(+)$ & \\
\hline Perseverance & & $(+)$ & & & \\
\hline Authenticity & $(+)$ & $(+)$ & & $(+)$ & \\
\hline Vitality & & $(+)$ & $(+)$ & $(+)$ & $(-)$ \\
\hline Love & & & $(+)$ & $(+)$ & \\
\hline Goodness & & & $(+)$ & $(+)$ & \\
\hline Social intelligence & & $(+)$ & $(+)$ & $(+)$ & \\
\hline Citizenship principles & $(+)$ & $(+)$ & $(+)$ & $(+)$ & $(-)$ \\
\hline Impartiality & & $(+)$ & & $(+)$ & \\
\hline Leadership & & $(+)$ & $(+)$ & & \\
\hline Forgiveness & & & $(+)$ & $(+)$ & $(-)$ \\
\hline Modesty & & $(+)$ & $(+)$ & $(+)$ & \\
\hline Prudence & $(+)$ & $(+)$ & & $(+)$ & $(-)$ \\
\hline Self-regulation & & $(+)$ & & $(+)$ & $(-)$ \\
\hline Appreciation of beauty & $(+)$ & & $(+)$ & $(+)$ & \\
\hline Gratitude & & & $(+)$ & $(+)$ & \\
\hline Mood & $(+)$ & & $(+)$ & $(+)$ & $(-)$ \\
\hline Hope & & & $(+)$ & $(+)$ & $(-)$ \\
\hline Spirituality & & & $(+)$ & $(+)$ & \\
\hline
\end{tabular}

Note: $(+)$ : positive relation; $(-)$ : negative relation.

C: Conscientiousness; E: Extroversion; K: Kindness; N: Neuroticism; O: Openness to experiences.

Conscientiousness demonstrates a similar relationship with the creativity, curiosity, critical thinking, love for learning, wisdom, bravery, perseverance, authenticity, vitality, social intelligence, citizenship principles, impartiality, leadership, modesty, prudence and self-regulation strengths. The extroversion trait explains love for learning, common sense, vitality, love, kindness, social intelligence, citizenship principles, leadership, 8 forgiveness, modesty, appreciation of beauty, gratitude, mood, hope and spirituality in a direct way. 
In addition, it is observed that the kindness trait presents a predictive power with all the character strengths, except for creativity, perseverance and leadership, emphasizing the relationship of forgiveness as the highest predictive power identified $(\beta=0.70, p<0.001)$. Finally, it is verified that the neuroticism trait negatively predicts critical thinking, sensibility, vitality, citizenship principles, forgiveness, prudence, selfregulation, mood and hope.

\section{Discussion}

The present study has reached its proposed objectives, and that it has been possible to demonstrate in an unprecedented way the combined contribution of demographic variables (age and sex) and personality traits in the recognition of the strengths of each individual. By using constructs and bringing social psychology closer to positive psychology, this study emerges as a relevant contribution to the study of human potentialities (McGrath, 2015; Seligman \& Csikszentmihalyi, 2000).

However, it should be taken into account that, even if the character strengths model is universal, investigations should consider the particularity of each region (McGrath, 2015; Park et al., 2006). In addition, it is observed that individual characteristics should also be considered; here, the results corroborate the assertion that the age variable does not influence the scores of most character strengths (Neto et al., 2014; Park et al., 2004). However, it is emphasized that this variable directly explains authenticity, impartiality and vitality, and mood traits. It suggests that over the years, people consolidate their beliefs, thereby becoming more confident and more willing to express themselves genuinely with other individuals. Also, it is observed that daily situations are faced with a better mood by young people, believing that there will be opportunities for overcoming them, while older individuals develop maturity and live their lives with enthusiasm and courage (Linley et al., 2007; Noronha \& Barbosa, 2016).

Another demographic variable studied was sex, with women scoring better, when compared to men, in critical thinking, authenticity, gratitude and spirituality, and men scoring better in creativity and bravery. It is important to note that there is an agreement between the results of the literature (Azañedo et al., 2014, Peterson \& Seligman, 2004, Romero et al., 2016), which indicate that it is easy for women to express their strengths in a particular way and a specific concern of men to demonstrate that they are able to adapt to situations and challenges.

The effect of these demographic variables (age and sex) was controlled and increased with the entry of personality traits into the explanatory model of strengths. With this, one can see that the openness to experience trait directly explains the character strengths, since it is noted that people who score the highest on this trait make use of their strengths that reflect this disposition to seek new experiences, when they become more cognitively engaged in acquiring new knowledge and attaining goals, aiming at different ways of living, with originality, joy and responsibility with their own choices (Farina \& Lopes, 2016; Nunes et al., 2010).

The conscientiousness trait predicts 16 strengths and reflects what is theoretically expected. It should be borne in mind that individuals with higher scores in this trait seek, in an organized way, their long-term goals; therefore, the strengths used aid in their perseverance and commitment, demonstrating a strong will and determination towards their own goals. They use strengths that also provide self-control in decisionmaking and maturity to firmly pursue the desired outcome (John et al., 2008; Liu \& Campbell, 2017).

The extroversion trait entered as a predictor variable of most strengths. Corroborating with Noronha and Campos (2018), as well as Depaula et al. (2016), in expressing that extroversion is one of the best predictors of character strengths. Its relation with character strengths therefore happens because extroverted individuals demonstrate more energy, enthusiasm and search for a harmonious social relation, demonstrating 
joy and happiness in their daily lives, use of character strengths to look for new things to learn, to deal with difficulties and experience the feeling of being an active person (Johnsen, 2014).

These same authors (Depaula et al., 2016; Noronha \& Campos, 2018) assert that the other trait considered among the best predictors is kindness. Similar results were found in the present study, in the same direction of previous studies, since it was the trait that best explained character strengths, leaving out only the model of creativity, perseverance and leadership. This strong relationship with strengths is expected, as people with a high level of kindness can easily demonstrate their strengths by having positive characteristics (e.g., goodness, friendliness, solidarity) that make daily life more harmonious. In addition, they use their character strengths to provide a healthier social life, which involves caring for and loving other people (McCrae \& Costa, 1987; McCrae \& John, 1992; Silva \& Nakano, 2011).

In another direction, the neuroticism trait is what predicts a smaller amount of strengths, inversely suggesting that the more people present emotional instability and negative emotionality, the more they are inhibited from expressing their strengths (Neto et al., 2014). Moreover, this trait presents a negative evaluation of representation as a characteristic, becoming undesired at high levels, which diverges from the striking characteristic of the strengths, which is an admittedly positive view, being useful and constructive in the daily lives of people. Therefore, individuals tend not to critically and sensibly evaluate everyday situations, not to care about the feelings of other people, acting without prudence and lightheartedness in their interpersonal relationships (Compton \& Hoffman, 2013).

It is emphasized that the virtues are positively recognized by society, listed by scholars as what to be sought after in a human being. However, the theoretical structure proposed originally of six virtues was not corroborated with empirical evidence, becoming only descriptive, and guiding investigations about the strengths of the individual, which together portray a virtuous character, used to deal with adverse situations and generate socially valued interpersonal relationships, therefore reinforcing the need to know the paths to virtues, this study focuses on character strengths, for when they are used in the daily lives of individuals, they serve as a path to virtue.

In this way, evidence is added of the predictive power of personality traits in the explanation of character strengths. Despite the theoretical and empirical distinctions (Johnsen, 2014, Noronha \& Campos, 2018), these two constructs hold important approximations for the study of the strengths of each individual. The present research also contributes with unpublished data from the Northeast region to the profile of the Brazilian population, preserving the specificities of each region, as well as advancing in national productions, in order to provide evidence to fill important gaps, mainly related to interventions as pointed out by Reppold, Gurgel, and Schiavon (2015), and the use of tests in the process of psychological evaluation (Pires, M.F.O. Nunes, \& Nunes, 2015). In addition, it approaches the themes of Social Psychology with positive aspects.

However, as limitations of the study, the following aspects are pointed out: the participants were only from the northeast region, with a non-representative collection and a non-experimental design, being recognized that it is impossible to generalize the results. It is worth noting that this was not included in the study objective and that all nine states in the Northeast region had their representatives. Thus, in future studies, it is expected to rely on samples from different regions of Brazil, expanding and comparing findings, as well as designing an experimental design of interventions and counting on the inclusion of other variables that are related to character strengths (e.g. human values, pro-social behavior, subjective well-being).

In this way, it is expected some progress in the area and the implementation of programs based on the learning and recognition of character strengths by each individual. With this, it is hoped to achieve the full development of human potential, above all, in facing adversities and promoting a healthy life. 


\section{Contributors}

R.N. COUTO participated in the preparation of the theoretical part, data collection, data analysis, and the elaboration of results and discussions. P.N. FONSÊCA participated in the elaboration of the theoretical part, besides the elaboration of the results and discussions and, lastly, reviewed all the production.

\section{References}

Andrade, J. M. (2008). Evidências de validade do Inventário dos Cinco Grandes Fatores de Personalidade para o Brasil (Tese de Doutorado não-publicada). Departamento de Psicologia, Universidade de Brasília.

Azañedo, C. M., Fernández-Abascal, E. G., \& Barraca, J. (2014). Character strengths in Spain: Validation of the Values in Action Inventory of Strengths (VIA-IS) in a Spanish sample. Clínica y Salud, 25(2), 123-130. http://dx.doi.org/10.1016/j. clysa.2014.06.002

Azucar, D., Marengo, D., \& Settanni, M. (2018). Predicting the Big 5 personality traits from digital footprints on social media: A meta-analysis. Personality and Individual Differences, 124, 150-159. http://dx.doi.org/10.1016/j.paid.2017.12.018

Compton, W. C., \& Hoffman, E. (2013). Positive psychology: The science of happiness and flourishing. Belmont, CA: Wadsworth.

Depaula, P. D., Azzollini, S. C., Cosentino, A. C., \& Castillo, S. E. (2016). Personality, character strength and cultural intelligence: Extraversion or openness as further factors associated to the cultural skills. Avances en Psicología Latinoamericana, 34(2), 415-436. http://dx.doi.org/10.19804/apl34.2.2016.13

Farina, M., \& Lopes, R. M. F. (2016). Perfil de idosos através do modelo dos cinco fatores de personalidade (Big Five): revisão sistemática. Diversitas: Perspectivas em Psicologia, 12(1), 97-108. http://dx.doi.org/10.15332/s1794-99 98.2016.0001.07

Goldsmith, R. (2017) The Big Five, happiness, and shopping. Journal of Retailing and Consumer Services, 31, 52-61. http://dx.doi.org/10.1016/j.jretconser.2016.03.007.

Hall. C. S.; Lindzey, G.; Campbell, J. B. (2000). Teorias da personalidade (4a ed.). Porto Alegre: Artmed.

Haridas, S., Bhullar, N., \& Dunstan, D. A. (2017). What's in character strengths? Profiling strengths of the heart and mind in a community sample. Personality and Individual Differences, 113(2017), 32-37. http://dx.doi.org/10.1016/j. paid.2017.03.006

John, O. P., Donahue, E. M., \& Kentle, R. L. (1991). The "Big Five" Inventory \& Versions 4a and 54. Washington: American Psychological Association. http://dx.doi.org/10.1037/t07550-000

John, O. P., Naumann, L. P., \& Soto, C. J. (2008). Paradigm shift to the integrative big five trait taxonomy: History, Measurement, and Conceptual. In O. P. John, R. W. Robins, \& L. A. Pervin. Handbook of personality: Theory and research (3rd ed., pp.114-158). New York: Guilford Press. Retrieved May 20, 2018, from https://www.ocf.berkeley. edu/ johnlab/2008chapter.pdf

Johnsen, C. (2014). Personality Traits and Character Strengths as Predictors of Well-Being (Master Dissertation). Eastern Illinois University, Charleston, IL. Retrieved May 21, 2018, from http://thekeep.eiu.edu/theses/1313

Li, L., Li, A., Hao, B., Guan, Z., \& Zhu, T. (2014). Predicting active users' personality based on micro-blogging behaviors. PLoS One, 9(1). e84997. http://dx.doi.org/10.1371/ journal.pone.0084997

Linley, P., Maltby, J., Wood, A., Joseph, S., Harrington, S., Peterson, C., ... Seligman, M. E. P. (2007). Character strengths in the United Kingdom: The VIA inventory of strengths. Personality and Individual Differences, 43(2), 341-352.

Liu, D., \& Campbell, K. W. (2017). The Big Five personality traits, Big Two metatraits and social media: A meta-analysis. Journal of Research in Personality, 70, 229-240. http://dx.doi.org/10.1016/j.jrp.2017.08.004

McCrae, R. R., \& Costa, P. T. (1987). Validation of the five-factor model of personality across instruments and observers. Journal of Personality and Social Psychology, 52(1), 81. http://dx.doi.org/10.1037/0022-3514.52.1.81

McCrae, R. R., \& John, O. P. (1992). An introduction to the five-factor model and its applications. Journal of Personality, 60(2), 175-215. http://dx.doi.org/10.1111/j.1467-6494.1992.tb00970.x

McGrath, R. E. (2015). Character strengths in 75 nations: An update. The Journal of Positive Psychology, 10(1), 41-52. http://dx.doi.org/10.1080/17439760.2014.888580 
Monteiro, R. P., Gouveia, R. S. V., Patrick, C. J., Carvalho, H. W., Medeiros, E. D., Pimentel, C. E., \& Gouveia, V. V. (2015). A psicopatia no contexto dos cinco grandes fatores da personalidade. Psico(PUCRS), 46(4), 461-471. http://dx.doi. org/10.15448/1980-8623.2015.3.20314

Neto, J., Neto, F., \& Furnham, A. (2014). Gender and psychological correlates of self-rated strengths among youth. Social Indicators Research, 118(1), 315-327. http://dx.doi.org/10.1007/s11205-013-0417-5

Niemiec, R. M. (2013). VIA Character strengths: Research and practice (The First 10 Years). In H. H. Knoop \& A. Delle-Fave (Eds.), Well-Being and cultures (pp.11-29). New York: Springer.

Noronha, A. P. P., Dellazzana-Zanon, L. L., \& Zanon C. (2015). Internal structure of the Strengths and Virtues Scale in Brazil. Psico USF, 20(2), 229-235. http://dx.doi.org/10.1590/1413-82712015200204

Noronha, A. P. P., \& Barbosa, A. J. G. (2016). Forças e virtudes: escala de Forças de Caráter. In C. S. Hutz (Org.), Avaliação em psicologia positiva: técnicas e medidas (pp.21-43). São Paulo: Hogrefre.

Noronha, A. P. P., \& Barbosa, A. J. G. (2018). O estudo das forças de caráter em brasileiros: análise de grupos etários. In T. C. Nakano (Org.), Psicologia Positiva aplicada à Educação (pp.125-140). São Paulo: Vetor.

Noronha, A. P. P., \& Batista, H. H. V., (2017). Escala de forças e estilos parentais: estudo correlacional. Estudos Interdisciplinares em Psicologia, 8(2), 2-19. http://dx. doi.org/10.5433/2236-6407.2016v8n2p02

Noronha, A. P. P., \& Campos R. R. F. (2018). Relationship between character strengths and personality traits. Estudos de Psicologia (Campinas), 35(1), 29-37. http://dx.doi.org/10.1590/1982-02752018000100004

Noronha, A. P. P. \& Martins, D. F. (2016). Associações entre forças de caráter e satisfação com a vida: Estudo com universitários. Acta Colombiana de Psicología, 19(2), 97-103. http://dx.doi.org/10.14718/ACP.2016.19.2.5

Nunes, C. H. S. S., Hutz, C. S., \& Nunes, M. F. O. (2010). Bateria Fatorial de Personalidade (BFP): manual técnico. São Paulo: Casa do Psicólogo.

Oliveira, C., Nunes, M. F. O., Legal, E. J., \& Noronha, A. P. P. (2016). Bem-estar subjetivo: estudo de correlação com as forças de caráter. Avaliação Psicológica, 15(2), 177-185. http://dx.doi.org/10.15689/ap.2016.1502.06

Oshio, A., Taku, K., Hirano, M., \& Saeed, G. (2018). Resilience and Big Five personality traits: A meta-analysis. Personality and Individual Differences 127, 54-60. http://dx.doi.org/10.1016/j.paid.2018.01.048

Parks-Leduc, L., Feldman, G., \& Bardi, A. (2015). Personality traits and personal values: A meta-analysis. Personality Social Psychology Review, 19(1), 3-29. http://dx.doi.org/10.1177/1088868314538548. Epub 2014 Jun 24.

Park, N., \& Peterson, C. (2009). Character Strengths: Research and practice. Journal of College and Character, 10(4), 1-10. http://dx.doi.org/10.2202/1940-1639.1042

Park, N., Peterson, C., \& Seligman, M. E. P. (2004). Strengths of character and well-being. Journal of Social and Clinical Psychology, 23(5), 603-619. http://dx.doi.org/10.1521/jscp.23.5.603.50748

Park, N., Peterson, C., \& Seligman, M. E. P. (2006). Character strengths in fifty-four nations and the fifty US states. The Journal of Positive Psychology, 1(3), 118-129. http://dx.doi.org/10.1080/17439760600619567

Peterson, C., \& Seligman, M. E. P. (2004). Character strengths and virtues: A handbook and classification. Washington: American Psychological Association.

Peterson, C., \& Park, N. (2006). Character strengths in organizations. Journal of Organizational Behavior, 27, 1149-1154.

Pilarska, A. (2018). Big-Five personality and aspects of the self-concept: Variable- and personcentered approaches. Personality and Individual Differences, 127, 107-113. http://dx.doi.org/10.1016/j.paid.2018.01.049

Pires, J. G., Nunes, M. F. O., \& Nunes, C. H. S. (2015). Instrumentos baseados em Psicologia Positiva no Brasil: uma revisão sistemática. Psico-USF, 20(2), 287-295. http://dx.doi.org/10.1590/1413-82712015200209

Reppold, C. T., Gurgel, L. G., \& Schiavon, C. C. (2015). Research in Positive Psychology: A systematic literature review. Psico-USF, 20(2), 275-285. http://dx.doi.org/10.1590/1413-82712015200208

Romero, N. A. R. C., Guajardo, J. G., \& Sanchez, A. M. (2016). La fortalezas de los mexicanos, um análisis desde la auttopercepción. Revista Iberoamericana de Psicologia: Ciência y Tecnologia, 9(1), 73-84. Recuperado el mayo 23, 2018, de http://revistas.iberoamericana.edu.co/index.php/ripsicologia/article/view/806

Schmitt, D. P., Allik, J., McCrae, R. R., Benet-Martinez, V., Alcalay, L., Ault, L., .. Zupanèiè, A. (2007). The geographic distribution of big five personality traits: Patterns and profiles of human self-description across 56 nations. Journal of Cross-Cultural Psychology, 38(2), 173-212. http://dx.doi.org/10.1177/0022022106297299

Seligman, M. E. P., \& Csikszentmihalyi, M. (2000). Positive psychology: An introduction. American Psychologist, 55, 5-14. http://dx.doi.org/10.1037/0003-066X.55.1.5 
Seibel, B. L., DeSousa, D., \& Koller, S. H. (2015). Adaptação brasileira e estrutura fatorial da escala 240-item VIA Inventory of Strengths. Psico-USF, 20(3), 371-383. http://dx.doi.org/10.1590/1413-82712015200301

Silva, I. B. \& Nakano, T. C. (2011). Modelo dos Cinco Grandes Fatores da Personalidade: análise de pesquisas. Avaliação Psicológica, 10(1), 51-62. Recuperado em maio 12, 2018 de http://pepsic.bvsalud.org/scielo.php?script=sci_ arttext\&pid=S1677-04712011000100006

Steger, M. F., Hicks, B., Kashdan, T. B., Krueger, R. F., \& Bouchard, T. J., Jr. (2007). Genetic and environmental influences on the positive traits of the Values in Action classification, and biometric covariance with normal personality. Journal of Research in Personality, 41, 524-539. http://dx.doi.org/10.1016/j.jrp.2006.06.002

Received: November 27, 2018

Final version: March 28, 2019

Approved: June 10, 2019 